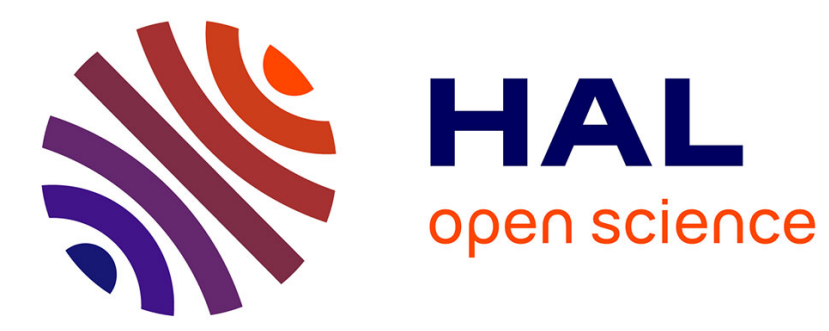

\title{
Production networks of the Asian automobile industry: Regional or global?
}

\author{
Bruno Jetin
}

\section{To cite this version:}

Bruno Jetin. Production networks of the Asian automobile industry: Regional or global?. International Journal of Automobile Technology and Management, 2018. halshs-01995206

\section{HAL Id: halshs-01995206 https://shs.hal.science/halshs-01995206}

Submitted on 26 Jan 2019

HAL is a multi-disciplinary open access archive for the deposit and dissemination of scientific research documents, whether they are published or not. The documents may come from teaching and research institutions in France or abroad, or from public or private research centers.
L'archive ouverte pluridisciplinaire HAL, est destinée au dépôt et à la diffusion de documents scientifiques de niveau recherche, publiés ou non, émanant des établissements d'enseignement et de recherche français ou étrangers, des laboratoires publics ou privés. 


\section{Production networks of the Asian automobile industry: Regional or global?}

Bruno Jetin, Associate Professor and Director of the Institute of Asian Studies, Universiti Brunei Darussalam

Paper presented at the International Conference "Change, challenges and opportunities: strategies for a sustainable future in Asia", School of Business and Economics, Universiti Brunei Darussalam, Brunei, 23-24 August 2017.

\section{Introduction}

China's rise and the emergence of developing Asia has shifted global demand to Asia (ADB 2010: 37) making it not only the factory but also the shopping mall of the world (Jetin 2012). This is especially true for the automobile. Since 2013, Asia sells more than twice the vehicle sales in North America and Europe and the gap is growing (Jetin 2015). In terms of production, Asia's prominence is even larger ${ }^{1}$. Excluding China, Asia's market is of the same size as the North American and European ones. Although the automobile is one of the most traded product at world level ${ }^{2}$, there is a consensus in the literature dedicated to the globalisation of the car industry that vehicle demand is primarily satisfied by regional production networks ${ }^{3}$ (Sturgeon and Van Biesebroeck 2011, Lung and Van Tulder 2004, Freyssenet et al. 2003). For instance, 78\% of the vehicles sold in North America in 2015 were produced in North America and 22\% were imported from other regions of the world. For the European Union, extra-regional imports amounted to only $15 \%$. In Japan, which is traditionally a closed market, total imports accounted for a meagre $7 \%$ of total sales ${ }^{4}$. In the case of Asia, defined as the reunion of East Asia, Southeast Asia and South Asia, the question arises as to whether the increase in automobile demand will be met above all by local supply and lead to a deeper regionalisation of Asian automobile production networks. The numerous free trade and investment agreements already signed by the countries of this vast region speak in favour of this. For instance, the Association of Southeast Asian Nations (ASEAN) ${ }^{5}$ has launched in 2015 the ASEAN Economic Community (AEC) which has eliminated tariffs among its main member states and the remaining ones will be completely removed in 2018 (Mikic 2016). Free trade agreements between ASEAN and all its main partners in Asia-Pacific have been signed (the so-called ASEAN+1) and a single comprehensive agreement, the RCEP is being negotiated to give Asia and the Pacific a unified trading framework. South Asian countries have created the South Asian Association for Regional Cooperation (SAARC) ${ }^{6}$ in 1985 which launched the South Asian Free Trade Area (SAFTA) in 2006.

All these elements point towards a deeper regional integration of Asia as a whole 7 . But in the automobile case, is there evidence of such an underlying trend towards more regionallyfocused production networks? What is the role of China in this process? Will the pull of the Chinese automobile market be strong enough to reorganise the existing Asian automobile production networks and in what way? Or will the existing automobile production networks stay more focused on a sub-regional and more fragmented level?

To address these questions, the article starts with a review of the literature on the globalisation versus regionalisation process with an emphasis on the automobile industry. Automobiles are now produced by fragmented production networks which are organised on 
a regional level in varying degrees. Unfortunately, most of the literature focuses on Northeast Asia, and less frequently on Southeast or South Asia, nor does it analyse the possible interactions between these subregions. In section 2, we try to fill this gap by looking at the global and regional trade of two kinds of automobile products over the period 2001-2015: the final products (completely built-up personal cars) and intermediate products (parts and components). A growing share of cars imported from or exported to Asian countries would be an indicator of regionalisation. Another important indicator is the trade in parts and components which reflects the importance of fragmented production networks. We analyse two kinds of data to track a potential regionalisation. Firstly, the trade distance of automobile products. The shorter the distance is, the stronger the regionalisation. Secondly, the national origin of imports and exports of automobile products in the key domestic and sub-regional Asian markets. The purpose is to check the importance of exchanges between subregions and the special role played by key actors, among them China.

Our main findings show that, for Asia as a whole, there is indeed a trend towards deeper regionalisation. Between 2001 and 2015, import and export distances of parts and components have decreased by $-1189 \mathrm{~km}$ and $-797 \mathrm{~km}$ respectively. For cars, the figures are $-262 \mathrm{~km}$ and $-731 \mathrm{~km}$ respectively. In 2015, 61\% of parts and components imported by Asia came from Asia up from $57 \%$ in $2001.43 .5 \%$ of parts and components were exported to Asia up from $33 \%$ over the same period. Regarding the final product, cars, only $26 \%$ were imported from Asia in 2015, down from 30\% in 2001 but the share of cars exported to Asia is growing to $29 \%$ of the total of exports, up from $12 \%$ in 2001 . This trend covers different dynamics at the subregional and national level. China's rise has a direct effect on the subregional automobile production networks as the share of Chinese parts and components is increasing in the imports of ASEAN, India, Japan and Korea. In this sense, China is really integrating all the subregions of Asia and is a carrier of regionalisation of the automobile industry. It partly substitutes the role played by Japan in the previous decades. But Japan's influence has not declined as much as its direct share in trade exchanges may suggest. Japanese companies use their numerous subsidiaries localised in all the subregions of Asia to trade parts and components within the context of fragmented production. A final finding is that integration between India and Southeast Asia is still marginal. Korea, despite the success of Korean brands on global markets, does not play a big role in regional integration. The regionalisation of Asian automobile networks is primarily a Japanese and Chinese affair.

\section{Regionalisation of Asian automobile networks: lessons learnt from the literature.}

Two strands of the literature are relevant for our study. The first analyses the fragmented production networks of various regions of the world to determine whether they are regionally or globally-focused. Trade flows are examined to see if trade within the region develops faster than trade with the rest of the world. Gross trade or trade in value-added are studied, the latter approach being more precise as it avoids double counting and involves all the activities at different stages that concur to the production of the final product. A new approach, the network analysis (De Benedictis and Tajoli 2011), gives a more realistic account by assuming that countries are nodes that are linked by trade flows that determine a network that have specific properties changing with time. The choice of a firm to trade from country $A$ to country B will also depends from the possibility of these countries to trade with country $C$ and/or D. This gives a comprehensive view of the architecture of trade network at a regional or global level created by firms when they established fragmented production networks. 
The second strand of literature focuses specifically on the automobile industry in the Asian context, in particular the trade and industrial policy of host countries. The regional integration initiatives, like the AEC and the ASEAN+1 trade agreements, are supposed to give more opportunities to automobile firms to better organise their network. But these subregional free trade agreements are different from one another leading firms to manage complex rules and influencing the way automobile networks are organised. Protectionism stays at a high level in some cases, or has been reduced but at different levels. The outcome is a sort of variable-geometry regional integration. We present the level of tariffs that apply to automobile products and review some recent trade agreements that are relevant for automobile networks.

\section{Fragmented production networks: towards the "global factory"?}

The consensus shared by all the studies is that production networks are initially regional. For (Baldwin 2013: 20:21), in each regional block, there are "headquarter" economies, like Germany or Japan, and "factory" economies, whose exports contain a relatively large share of imported intermediates ${ }^{8}$, like China and India. He discerns the existence of a "Factory Asia, Factory North America, and Factory Europe" because network trade of intermediates is more intense inside each block. Several subsequent studies have refined the original mapping of production networks (Sturgeon and Memedovic 2010) to better identify the share of foreign intermediates in a country's exports, the length of the production networks, the position of a country in it and its distance to final demand. These improvements have also helped to better estimate the regional character of the production networks.

For instance, (De Backer and Miroudot 2014) use a new OECD and WTO data base built in value added terms which covers 58 countries, including East and Southeast Asian countries ${ }^{9}$, and 37 industries over the period 1995-2009. In 2009, the automobile industry counts among the highest fragmented industry ${ }^{10}$ and among the most internationalised. But in each of the three blocks under review, (Europe, NAFTA, Asia), the regional organisation of the production dominates. In Asia, the sourcing of intermediates comes largely from within the region with a higher share of domestic intermediates in China, Japan, Korea and India and a higher share of foreign intermediates in the Southeast Asian countries. China, Japan and Korea are also more specialised in upstream activities and their participation rate to fragmented production is at an intermediate level, while Thailand, Indonesia, the Philippines and Malaysia are more specialised in downstream activities and have a lower participation rate. Vietnam and Cambodia are closer to final demand because they are specialised in assembly activities and have almost no participation in network trade. The authors observe that the most successful countries are those that have specialised in intermediates products and have increased their "upstreamness". This success has enabled the new consumers of these countries to afford a broader range of final products. As a consequence, trade in final goods and services has increased as much as trade in intermediaries. The economic growth originating initially from a higher insertion into fragmented production networks leads in the end to more demand of final products.

(Helble and Ngiang 2016) also find evidence that trade in intermediate and capital goods within East Asia has surged over the period 1999-2014 and that since 2011 more and more final goods are being reoriented towards East Asia. East Asia's prolonged prosperity has been translating into stronger demand for local consumer goods. This will enable East Asia to 
capture higher value-added downstream activities that traditionally accrue to European and American companies. Average lead times from Asian companies to Asian customers should fall leading to higher margins and lower prices. The authors base their conclusions on the analysis of export distances of Japan and Korea (merged into one group), China and ASEAN ten Member States $(A M S)^{11}$. They distinguished four commodity groups: primary, intermediate, capital and consumer goods. A falling distance means that North America and Europe lose importance to the benefit of markets closer to East Asia and East Asia itself. They complete this first set of evidences with the use of a gravity model that confirms the change of East Asia's trade.

Their results reveal that primary and intermediate goods are shipped over short distances while capital and consumer goods are exported over longer distances which is consistent with the assumption that the former are included in regional production network. Interestingly, they show that the trade distance of the four commodity categories have fallen over the period for Japan, Korea and AMS, while they have increased in the Chinese case. For Japan and Korea combined, the trade distance of intermediate goods decreased from over $7,000 \mathrm{~km}$ in 1999 to 5,900 km in 2003 and is now stabilised around 5,500 km in 2014. The trend is almost the same for AMS, where they have declined from around 7,000 km in 1999 to around $5,800 \mathrm{~km}$ in 2014. Japan and Korea now export consumption goods over a distance of around 8,500km (8,800 km for AMS) down from around 9,500 km in $1999(10,400 \mathrm{~km})$. Capital goods followed the same pattern and are now exported over a distance of around $7,500 \mathrm{~km}$ in both group of countries. This provides evidence that East Asian production networks were mostly established in the early 2000s. Capital and intermediate goods were increasingly used by Asian production networks and a growing share of consumption goods produced in Asia were sold in Asia. For instance, in 2014, 42\% of the consumer goods produced by ASEAN stayed in East Asia, up from 29\% in 1999. On the other hand, China export distances have regularly increased and have stabilised at the end of the years $2000 \mathrm{~s}$ at around $6,500 \mathrm{~km}$ for intermediate, 7,500 km for capital and 8,000 km for consumer goods. China, which used to be a place of labour-intensive assembly of imported intermediates, is now itself an exporter of intermediates and also of capital goods, which now exceed those of Japan and Korea combined. China has become a global factory for the four categories of goods which are shipped to Asia and the rest of the world. Overall, these results confirm the assumption that East and Southeast Asia regional integration is driven not only by supply, the fragmented production networks, but also by demand. The results of the gravity model confirm these conclusions. Notably, "sharing a common land border has become increasingly important for consumption good exports" ( $p$ 45).

Conversely, (Los et al. 2015) find that the regional fragmentation is still dominant, but that over the last 15 years, the global fragmentation has increased faster than regional fragmentation. Using the new World Input-Output Database for the years 1995-2011, covering 40 countries in 3 regions ${ }^{12}$, for 14 manufacturing industries, they identify the value added produced domestically, within the region to which the national producer belongs, and outside the region. For transport equipment products ${ }^{13}$, which is the category closest to the automobile products, the share of foreign value added at world level amounted to around $30 \%$ in 2008 , up from $20 \%$ in $1995^{14}$. The $9 \%$ increase over the period puts it to the fifth level among the 14 industries. Still, it means that in 2008, 70\% of the value added in transport equipment products were produced domestically. In the three regions, for the 14 manufacturing industries, regional and global value added rose, the latter more than the former. Of the three regions, East Asia displays the highest increase in foreign value added 
(+9.5\%) over the period 1995-2008 and in each of the Asian countries, the global share increased more than the regional share. In China, the regional share actually decreased by $1 \%$. This result contradicts the several case studies, notably that of (Baldwin and LopezGonzalez 2015) that describe how China imports from Japan, Taiwan and South Korea components that are assembled to form final products that are shipped to the rest of the world. It may be explained by the narrow definition of the region, which excludes the other Asian subregions which are increasingly integrated with East Asia. In another publication, (Timmer et al. 2015) show for the specific case of the transport equipment industry ${ }^{15}$, that in the six major producing countries, the share of the foreign value added in final output was on the rise over the period 1995-2011, with many differences across countries. In the major European countries, it was in a range of $35 \%$ to $42 \%$ in 2011, up from a range of $22 \%$ to $28 \%$ in 1995. In the USA, after a stagnation of around 15\% between 1995 to 2003 , the foreign value added increased to around $23 \%$ in 2008, and after the crisis in 2009, it was around $26 \%$ in 2011. In Japan, the share of foreign value added was initially very low in 1995 (5\%), and had tripled in 2011. China followed a different path. Its share stagnated around $15 \%$ until China joined the WTO in 2001, after which it peaked to $25 \%$ in 2004. It then decreased regularly until the crisis of 2009, then resumed an increasing trend to around 22\% in 2011. The authors explain this evolution by the strong growth of automobile components output in China which substituted imports for a while. The breakdown of the foreign value added in regional and global share follow the same pattern as observed for the average of the 14 industries. For China, the regional share of value added in the final output of transport equipment has decreased by $-1 \%$ between 1995 and 2008, while the global share has increased by $7 \%$. China is clearly more globally-oriented than regionally-oriented. For Japan and South Korea, the global share has increased faster (respectively $+9 \%$ and $+8 \%$ ) than the regional share (respectively $+3 \%$ and $+5 \%$ ). For these two countries, regionalisation and globalisation are a complementary rather than contradictory phenomenon. In Taiwan, the global share has increased less $(+2 \%)$ than the regional share $(+3 \%)$ pointing to a stronger process of regionalisation. These results must be considered with caution. It remains to be seen whether the increasing upward trend of the share of foreign value added in total automobile output will continue in the future and reflect a structural change in the value chain. Or, if it is the consequence of a business cycle and in particular the strong recovery of the North American automobile market after the Great recession. North America now import much more components from Asia than before.

(Amighini and Gorgoni 2014) tackle the question of a structural change in the international organisation of automobile production by using network analysis. They analyse the trade data of 30 automobile parts and components (at five digits' level) which are aggregated into four component groups: engines, rubber and metal parts, electrical and electric parts and miscellaneous parts. This is an improvement from Timmer et al (2015) as the analysis now focuses on the core of automobile network trade. They scrutinise the bilateral trade of these components for all the countries covered by the UN Comtrade database which accounts for at least 1\% over the world's total for the years 1998 and 2008. Countries are grouped in mutually exclusive regional groups ${ }^{16}$. Trade networks are graphed with countries representing nodes and directed trade flows as the ties among them. Networks are different in size and composition among the four groups and change with time. Overall, the results point to a more hierarchical structure, especially for the case of electrical and electric parts and miscellaneous parts, with a decline of the share of two-way trade within each network. In all networks, this hierarchy follows a core-periphery structure, in which all 
the countries of the periphery are connected to the core but have almost no connection between them. The composition of the core has changed, notably with the entry of China, and the core concentrates a higher share of world transactions. There are more countries in the periphery and they command a smaller share. The networks are therefore more vertical. As regard the degree of regionalisation of production, in two among the four component networks, there is a rise of regional production at world level ${ }^{17}$. But in Asia, there is the emergence or strengthening of a regional production network in three among the four component groups ${ }^{18}$. Indonesia, Thailand and India have appeared in more networks in 2008, while the Philippines has disappeared and Malaysia is only present in the electric and electrical component category. In this same category, Japan, which used to import from Asian countries to export to Europe, has passed this role to China where it has relocated much of its production capacity. In the miscellaneous parts group ${ }^{19}$, there was no Asian production network in 1998, with only China importing from Germany and Japan exporting to the USA. In 2008, China has become a crucial node of an Asian network, importing parts from South Korea and Japan and exporting to the USA, and linking European and North American networks with Japan. Japan exports parts to Thailand and Indonesia where Japanese carmakers have delocalised part of their production. In the rubber and metallic parts category, there is a general decline of regional networks. Asian countries (China, Japan, South Korea, Indonesia and Thailand) supply the USA, but they do not share production between them hence the absence of an Asian network in this category. Engine is a truly global trade network, with reduced core-periphery structure in which all regional groupings are intertwined. While European and North American networks have declined, Asian countries have deepened their regional organisation with the arrival of new actors such as India and Thailand.

In summary, the three articles analysed above point to a process of regionalisation of automobile production networks in Asia which is differentiated among countries and among products. These differences are expected due to the large differences in economic development of Asian countries and the variety of their automobile industries. The region hosts two countries (Japan and South Korea) with domestic global brands but relatively small markets, two large markets (China and potentially India) without domestic global brands, and a group of middle-income countries with significant markets but almost no domestic producers. These different subregions have different strategic interest regarding their automobile industry. We now look precisely at the trade policies that have been adopted in Asia to accommodate fragmented production on one side while protecting to a certain extent the national production, and in some cases the national producers, on the other side.

\section{Asian automobile integration: between regionalisation and protection.}

Production networks are more sensitive to trade costs (tariff and non-tariff barriers, transport and logistic costs) as intermediate products cross borders more frequently than final goods. There may be an escalating effect when tariffs apply to the value of the good and when the number of stages of production is high (Escaith and Inomata 2013: 145). The different Asian subregions have signed trade agreements and invested in infrastructure to reduce trade costs but they remain fragmented due to the persistence of high tariffs and non-tariff barriers.

ASEAN is the most advanced initiative. Since the end of the eighties, Japanese carmakers had pressured Southeast Asian states to reduce tariffs on vehicles, parts and components to avoid duplicating investments in ASEAN countries where markets were too small to justify a fully integrated automobile production. They wanted to foster within-ASEAN 
trade to achieve higher economies of scale (Yoshimatsu 2002, Guiheux and Lecler 2000). Mitsubishi Motors proposed a plan, the Brand-to-Brand (BBC) scheme that was adopted in 1988. It granted tariff reduction and local content accreditation to carmakers to consolidate production of particular parts in one country and then export them to plants in other ASEAN countries. This scheme was instrumental in leading other carmakers like Toyota to invest in ASEAN to establish a complementary production system, which was actually the first step towards the creation of a more fragmented production system. However, ASEAN's decision in 1992 to create an ASEAN Free Trade Area (AFTA) by 2008, and the adoption of the Common Effective Preferential Tariff (CEPT) scheme implemented in 1993, led ASEAN to scrap the BBC scheme in 1995. The opposition of Japanese carmakers and part producers like Denso, of the Japanese Automobile Manufacturers Association (JAMA), and of the Japanese government convinced ASEAN to substitute the BBC by a new scheme, the ASEAN Industrial Cooperation (AICO) which included carmakers and part producers. The new scheme did not work well initially because of conflict over the implementation of the AICO between multinational companies and governments willing to protect their national companies. The Asian crisis of 1997-98 forced the ASEAN countries to relax their requirements. Notably, they waived the 30 percent national equity requirement during the period 1999-2000 because many local companies were bankrupt and needed to be bailed-out by their foreign partners. The number of approved applications increased and ASEAN-wide production networks began to operate. The gradual implementation of the AFTA which reduced tariffs to almost zero by 2010 between 6 ASEAN founders plus Brunei Darussalam ${ }^{20}$ was an additional factor. According to (Okabe and Urata 2014), it had a positive and significant impact on the intra-ASEAN imports of automobile parts and components. It was later completed with the launch of the ASEAN Economic Community in November 2015 which created a "single market and a single production base" (Jetin and Mikic 2016). ASEAN latecomers, Cambodia, Laos, Myanmar and Vietnam, also called CLMV countries, were given until 2018 to remove tariffs completely ${ }^{21}$. At that date, trade of cars and of parts and components will be completely tariff-free, provided that at least $40 \%$ of the value is produced within ASEAN. This rule of origin can be easily met because the local content can be accumulated across several ASEAN members (for instance, $20 \%$ in Thailand, $10 \%$ in Indonesia and $10 \%$ in Malaysia). This is precisely the logic of fragmented production and reflects the ongoing influence that carmakers have exerted on ASEAN agreements. This creates an incentive to produce within ASEAN to benefit from the exemption of taxes and may strengthen a multi-layered structure (Kobayashi et al. 2015). The first layer will be made of Japanese and US car makers with a high level of local content $(60 \%$ and above). They are located in Thailand, Indonesia and to a lesser extent in Malaysia. The second layer is made of CKD assemblers with at least a 40\% local content. They are based in Vietnam, Indonesia, Malaysia and Thailand. The third layer is made of CKD assemblers of brands that do not fulfil the $40 \%$ local content requirement. These assemblers will be marginalised in ASEAN as they will have to pay tariffs on imports of CKD units while their competitors which satisfied the local requirement content will not. Finally, for parts and components, the logic would be that tier-one producers are localised near car makers in Thailand, Indonesia or even Malaysia while tier-two and three producers are localised in CLMV countries where wages are lower (Kobayashi and Jin 2015). Some plants have already been built or offshored in Cambodia and Laos, but the phenomenon is for the moment of limited importance. On the long-term, it is also possible that ASEAN's major automobile producers, Thailand and Indonesia, become the two main hubs from which cars are exported to the rest of Southeast Asia22. 
At the same time, free trade areas and foreign investment agreements were signed by ASEAN and China, Korea, Japan and India ${ }^{23}$. A trade agreement has also been signed between South Korea and China and implemented in 2015. An agreement between China, Korea and Japan is still being negotiated. China has signed a free trade agreement with Pakistan in 2007 but a trade arrangement with India is still at the stage of discussion. India and Korea have signed an agreement which entered into force in 2010. On paper, these agreements give a formal framework to existing business connections and add new incentives to extend production networks to the whole Asia. But in practice, the benefits for the automobile trade are minimal because in many cases cars and auto components are still subject to the sensitive or highly sensitive list (Abe 2013), (Pasha 2011) and tariffs between ASEAN and its main Asian partners remain high. Table 1 and 2 show the tariffs for the year 2016 between selected countries of Northeast, Southeast and South Asia for cars (HS 8703) and auto parts and components (HS 8708) ${ }^{24}$.

If we exclude trade within ASEAN where tariffs have been scraped, tariffs on built-up vehicles remain high, ranging from 20 to $25 \%$ in the case of China, up to a prohibitive $100 \%$ in India. For instance, China applies a $23 \%$ rate on imports of Korean cars although the two countries have just signed a "free trade" agreement. Despite Korean carmakers' lobbying, the agreement maintains automobile products in the list of sensitive products because the Chinese government wants to protect its market and to oblige Korean automobile producers to invest and manufacture in China (Schott et al. 2015). Combined with the $9 \%$ tariff on Korean parts, this impedes Korean car makers and parts producers to directly integrate their plants in Korea with those of China.

Except for Brunei Darussalam and Singapore, where there is no tariff at all, other ASEAN countries apply high tariff too. For instance, Thailand imposes a tariff of $40 \%$ on the import of Chinese cars, of $62 \%$ and $66 \%$ on Korean and Japanese cars, and $75 \%$ on cars imported from South Asian countries. Vietnam does the same with a tariff around $55 \%$ while in other ASEAN countries tariffs range between $20 \%$ and $30 \%$. South Asian countries are also protectionist, Pakistan being second to India with a tariff of $87 \%$. Such a high level of protectionism is a major hindrance to a regional trade of finished vehicles between the three parts of Asia. Apart from ASEAN, trade of vehicles within Northeast and South Asian countries is also impaired by the same tariff barriers. For instance, trade between the two largest South Asian countries, India and Pakistan is virtually impossible for political and protectionist reasons although it would be mutually beneficial for both countries (Nag 2017, Ahmed and Batool 2017).

Trade of parts and components tends to be less protectionist. China has low tariffs on ASEAN products and higher with Northeast and South Asian products which fits with its role of assembler Southeast Asian intermediates. ASEAN countries have high tariffs, especially on imports from South Asian countries which are direct competitors due to their low wages. Thailand, which hosts an important supply base, is more protectionist than other ASEAN countries with one exception. Thailand signed an agreement with India in 2004 that remove tariffs on gearbox and parts for spark ignition in engines, while for the rest, a $10 \%$ tariff is applied on average. Pakistan and Sri Lanka impose high tariff to protect their suppliers which makes virtually impossible the establishment of auto parts production networks within South Asia.

Even when tariffs are low or have been eliminated as it is the case within ASEAN, nontariff barriers are an issue and contribute to maintaining high trading costs. For instance, the rule of origin is complicated to apply due to changes of classification and of value content 
(Cheewatrakoolpong et al. 2013). Another example is the lack of harmonisation of technical regulation within Asia. In ASEAN, which is supposed to be a single market since 2005, JAMA is advocating for the adoption of a mutual recognition agreement (MRA) on vehicle regulation in areas such as vehicle type approval, safety policies and fuels to provide a legal framework for auto production systems. A basis could be the 1958 agreement adopted at the United Nations. Under an MRA, contracting parties within ASEAN agree to recognise each other's approval without the need to re-certification. This would be a major trade facilitation for companies which are heavily involved in ASEAN network trade. JAMA has established the "industry forum of Southeast Asia" in 2015 (ISEA) which held its first meeting in Kuala Lumpur in 2015 to lobby for the adoption of this MRA. It is also very active in the different institutional working groups set by ASEAN and business circles to promote the MRA. Yet, after more than 10 years of discussion, the agreement is still not adopted.

Finally, to get a complete picture, it is important to consider non-tariff comprehensive trade costs such as non-tariffs measures compliance costs, costs associated with transport, logistics and facilitation services, among others ${ }^{25}$ (Duval and Feyler 2016: 156-57). Within ASEAN-4 (Indonesia, Malaysia, Philippines and Thailand), they amount on average over the period 2007-2012 to $77 \%$ of the value of the traded goods, despite all the initiatives taken to reduce such costs in the perspective of the AEC. Trading within the CLMV countries is even more expensive with a cost of $128 \%$. Trade cost within SAARC is also high, adding $108 \%$ to the value of the goods. This must be compared with the trade costs within the EU-3 (France, Italy and the United Kingdom) (44\%) and within NAFTA (46.5\%). This shows the progress to be made by the ASEAN EC and SAARC to become a single market or simply more integrated. Duval and Feyler observes that trade costs between Northeast Asian countries (China, Japan and South Korea) are much lower (51.4\%), although there is no trade agreement in force yet between the three countries. Another important result is that trade costs between ASEAN-4 and Northeast Asia are much lower than those between ASEAN-4 and CLMV economies $(165 \%)$ or with SAARC (121\%). This reveals a strong connectivity between the two subregions and explains the strength of production network between ASEAN-4 and Northeast Asia and in particular China. Conversely, it shows that ASEAN-4 is not much integrated with the rest of ASEAN and with SAARC.

In summary, Asia is still a fragmented region. With the exception of Japan and Korea, all the other countries have maintained a protectionist policy to oblige carmakers and component suppliers to invest and produce locally and to protect domestic companies from direct foreign competition. This affects network trade within Northeast Asia and within South Asia, while ASEAN is the only subregion that has made progress towards a single market. It also limits network trade between Northeast Asia and South Asia and between South Asia and Southeast Asia. Network trade of auto parts and components between Northeast and Southeast Asia is the only one which enjoys low tariff and non-tariff barriers and firms' initiatives to reduce other trade costs. In the next section, we look at how automobile firms have dealt with this framework to manage their production network.

\section{Checking the fact: Is there evidence of a regionalisation of Asian automobile production networks?}

To check the existence of a regionalisation process, we look at two sets of indicators. Firstly, the trade distance of the major automobile producers and markets in Asia. A short distance means that trade operates at the regional level and conversely a long distance means 
that trade with other regions of the world dominates. Secondly the geographical origin of automobile trade gives more insights about the exchanges between the different Asian subregions. We use ICT investigation tool named "Trade Competitiveness Map" 26 based on COMTRADE database and the Harmonised System Classification (HS) ${ }^{27}$ revision of 2012. Automobile products (category 87 ) $^{28}$ are defined as "Vehicles other than railway or tramway rolling stock, and parts and accessories thereof" and can be divided into the category "vehicles for the transport of less than 10 persons" (hereafter "cars", category 8703) and into "vehicle components and parts" (hereafter, "components", category 8708$)^{29}$. We start by presenting the trade distance for cars, components and total products for selected countries and regions of the world for the year 2015 and then focus on the evolution of the distances for Asia only.

Table 3 and 4 present respectively the average import and export distances of different regions of the world. At global level, cars are traded at an average distance close to the world average while automobile components are traded on shorter distances (around 4,000 km) which is a first indication that components are used by regional rather than global production networks. Nonetheless, there are important variations across the different region of the world.

Asia mostly trades cars on very long distances $(7590 \mathrm{~km}$ for imports and $8,825 \mathrm{~km}$ for exports), much above the respective distances of total products in Asia (5,455 km and 5,775 $\mathrm{km})$ and above world level $(5,125 \mathrm{~km}$ and 4,695 km). Asia imports components from an average distance of 5,121 km which is shorter than the longest East-West distance (KarachiTokyo, 6,910 km) or Northeast-Southeast distance (Jakarta-Tokyo, 5,750 km). This implies that Asia as a whole imports components that come mostly from Asia itself which is consistent with the existence of a regional production network. These components are mostly exported outside of Asia. Looking at Asia's different subregions, we observe the following:

Northeast Asia follows the same pattern for components that are imported mostly from Asia and exported beyond Asia. For cars, the respective trade distances are even longer $(8,027 \mathrm{~km}$ and $9,048 \mathrm{~km})$ than for Asia which shows that they are really a global product in this subregion where the income per capita is high.

ASEAN imports cars from a much shorter distance $(5,221 \mathrm{~km})$ than Northeast Asia

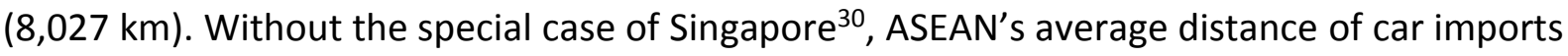
would be even shorter $(4,069) \mathrm{km}$. This is inferior or equal to the longest possible distances between ASEAN and Northeast Asia or between ASEAN and South Asia ${ }^{31}$. For components, the trade import distance is even shorter $(4,790 \mathrm{~km})$. This means that cars are and components are mostly supplied by Asia and ASEAN itself. ASEAN export distances of cars and components are longer than import distances but much shorter than in the Northeast Asia case which confirms that ASEAN is on average more regionally focused.

South Asia imports cars from a rather short distance on average $(5,111 \mathrm{~km})$, like ASEAN, but imports components from a longer distance $(5,612 \mathrm{~km})$. Knowing that the longest distances between the capital cities from South to Northeast Asia are around 6,900 $\mathrm{km}^{32}$, this implies that South Asia's automobile imports are on average within the confines of Asia. Conversely, South Asia exports cars and components over very long distances $(8,239 \mathrm{~km}$ and $8,447 \mathrm{~km}$ ), superior to the distances for all products. This reflects primarily the export pattern of India which exports primarily outside of Asia.

NAFTA member states (North America Free Trade Agreement) import significantly cars and components from outside their region. Car and component import distances (respectively $5,809 \mathrm{~km}$ and $5,266 \mathrm{~km}$ ) exceed by $1,600 \mathrm{~km}$ or more the longest distance between two capital cities of the region (Mexico City and Ottawa are 3,600 km distant). It means that not only 
NAFTA imports many cars from the rest of the world but its production network is also more globalised. NAFTA exports on shorter distances $(4219 \mathrm{~km}$ for cars and 2,741 km for components). It means that North American firms import components from abroad that are incorporated in the local production network to produce other components that are exported on average within the borders of NAFTA.

At the other end of the spectrum, Europe (the European Union 28 member states) appears as the most regionalised automobile production network. Cars and components are imported from less than $2000 \mathrm{~km}$, which is $1000 \mathrm{~km}$ less than the average for all products $(3000 \mathrm{~km})$ and less than the longest possible distance between two European capital cities (Lisbon - Helsinki, 3,350 km). Export distances of cars $(5,130 \mathrm{~km})$ reveals that Europe exports much of its production out of Europe but components are primarily exported within the European borders $(2,508 \mathrm{~km})$ which is slightly less than the average for all products and confirms that the production network is very self-centred.

To confirm the hypothesis of a regionalisation of Asian production networks we focus on automobile component imports which is a good proxy of network trade. Figure 1 shows the evolution of import distance of auto components of Asia and its subregions over the period 2001-2016. One can see that Asia's import distance has fallen over the period from 6,635 km in 2001 to 5,290 km in 2016. In Northeast Asia, the fall was even more pronounced especially during the financial crisis of 2009 when automobile production dropped in major automobile markets. Although Northeast Asia's import distance recovered after the crisis, it stayed much below the level of 2001 and tended to decline after 2014 despite the boom in automobile demand and production in North America and Europe. The import distance of components in ASEAN stayed below $5,000 \mathrm{~km}$ after the fall at the start of the period. South Asia has followed the same pattern. Overall, a regionalisation of Asian production system is underway.

We now look into more detail in the trade of components within and between the different Asian subregions to better explain this process of regionalisation.

Figure 2 presents the breakdown of Asia imports of automobile components by subregions. In 2016, around $61 \%$ of Asian automobile component imports were coming from Asia, up from $57 \%$ in 2001 . This reflects a high level of productive integration, less than in the European Union (EU 28 countries) where it was around $83 \%$ but higher than in North America (NAFTA) where it was around $57 \%$ in $2016^{33}$. The small increase in regional sourcing of auto components in Asia between 2001 and 2016 is explained by a 5.7\% increase of component imports coming from Northeast Asia and a 3.7\% increase from South Asia offset by a reduction of around 5\% in ASEAN. Compared to Northeast Asia and ASEAN, South Asia is still a small supplier of components to Asia but its share is slowly but steadily increasing. To have a better view of the changes occurring behind this broad regionalisation process, we now look at the share of China and Japan, the two largest producers, in the imports of components of the main producers of the region. Starting with Japan, Figure 3 shows that in the largest ASEAN economies, there has been an overall reduction of the share of Japan in their imports of automobile components. The fall is especially important in the case of Indonesia, the Philippines and Thailand, less so for Malaysia and Vietnam. Conversely, Figure 4 shows a spectacular increase of Chinese components in the imports of the Southeast Asian countries. It is especially strong in the case of Vietnam, Malaysia and Thailand, less so in the Philippines and Indonesia. The rise of China is also occurring in India. Figure 5 shows that the overall increase of Asia in India's component imports hides a sharp drop of Korea, where the Hyundai group has established a strong presence, and a decline of Japan, while China's share has 
improved from almost nothing in 2001 to around 16\% in 2015. It is also notable that ASEAN has doubled its share from 6.5\% in 2001 to around 13\% in 2015 as much as Japan. Finally, when we look to Japan, we observe (see Figure 6) that the sharp rise in Asian sourcing is mostly explained by the increase in imports from China and to a lesser extent from ASEAN, and a very small increase from South Asia. Imports from NAFTA and the EU have declined from their leading role in 2001. The regionalisation of Asian productive networks is primarily driven by China, but what about China itself? Figure 7 shows that after an initial surge up to $68 \%$ in 2005, China's imports of Asian auto components have declined steadily and have been replaced by imports from Europe. The latter now account for $47 \%$ of Chinese imports, higher than imports from Northeast Asia which mainly come from Japan and South Korea. Imports from ASEAN barely amount to $10 \%$ and imports from South Asia are negligible. This is explained by the success of European and mostly German brands in the Chinese market. High value added components like car bodies, transmission, gearboxes, steering and suspension equipment and headlight systems are imported to equip cars produced in China (Bungsche 2010). One limit to the regionalisation of Chinese automobile production networks is the fact that Asian and Chinese brands are not overwhelmingly dominating the Chinese car market. Massive imports of components from Europe makes Chinese production network more global than regional. China being the largest automobile market, this may explain why the regionalisation of Asian automobile production networks is still modest compared to its potential.

\section{Conclusion}

This article tried to assess the level and trend of regionalisation of automobile production network in Asia. Asia has the potential to become the most integrated automobile region of the world thanks to the presence of large markets, the existence of global producers in Japan and Korea and the possible emergence of new ones from China and India, and thanks to initiatives taken by governments to promote regional integration. It can also be mentioned of an already long experience of regional supply chains. All these elements combine to make Asia the best place for firms to spread automobile fragmented production throughout the whole region to minimise cost and maximise economies of scale.

Our investigation reveals a real but slow progress of such a regionalisation over the period 2001-2016. Trade of parts and components between Northeast Asia, Southeast Asia and South Asia is increasing thanks to the network created by carmakers and component suppliers. But these progress have been slow due to the persistence of protectionism among the three main subregions and within them. Tariff and non-tariff barriers are still high because national governments want to oblige foreign automobile firms to invest and produce locally and also because local producers still ask for a high level of protection especially in South Asia. As a consequence, network trade between the three subregions remains below its potential. The slow progress in the creation of an Asia-wide free trade area, despite the existence of projects like the RCEP does not bode well for the future. An aggravating factor is that the automobile industry being a major contributor to economic growth, it tends to be put on a sensitive list, which means excluded from free trade. One consequence is an unequal process of development of regional trade. ASEAN having dismantled its tariffs barriers is in a position to attract production and trade within ASEAN that would have developed otherwise between India and some ASEAN member state. Agustin and Schroder give examples of such distortion of trade (2014). Another problem is the unequal level of development, the rivalry or even antagonism between countries, for instance within South Asia, which impedes the creation of an integrated subregional market. The combined effect of these multiple factors is a very 
heterogeneous process of regionalisation. Southeast Asia, Japan and Korea are becoming more tightly integrated to China, while South Asia lags behind. But analysing regional integration through the lens of national borders may in fact be misleading. On the one hand, China appears to substitute Japan as the main carrier of regionalisation. On the other hand, Japan seems to be the main benefactor of this process of regionalisation. According to Jama (op cit), Japanese automobile companies account for around $80 \%$ of ASEAN automobile exports and they also account for a good share of Chinese imports and exports of auto components. Japanese firms, and to a certain extent Japan, may be the big winner behind China's rise.

Tables and Figures. 
Table 1. Equivalent ad valorem tariff applied by importer country to exporter country on motor vehicles (HS 8703)

\begin{tabular}{|c|c|c|c|c|c|c|c|c|c|c|c|c|c|c|c|c|c|c|}
\hline $\begin{array}{l}\text { Importer } \\
\mathrm{s}\end{array}$ & $\begin{array}{l}\text { Chi } \\
\text { na }\end{array}$ & $\begin{array}{l}\text { Jap } \\
\text { an }\end{array}$ & $\begin{array}{l}\text { Sou } \\
\text { th } \\
\text { Kor } \\
\text { ea }\end{array}$ & $\begin{array}{l}\text { Taiw } \\
\text { an }\end{array}$ & $\begin{array}{l}\text { Bru } \\
\text { nei }\end{array}$ & $\begin{array}{l}\text { Cambo } \\
\text { dia }\end{array}$ & $\begin{array}{l}\text { Indone } \\
\text { sia }\end{array}$ & $\begin{array}{l}\text { La } \\
\text { o } \\
\text { PD } \\
\text { R }\end{array}$ & $\begin{array}{l}\text { Malay } \\
\text { sia }\end{array}$ & $\begin{array}{l}\text { Myan } \\
\text { mar }\end{array}$ & $\begin{array}{l}\text { Philippi } \\
\text { nes }\end{array}$ & $\begin{array}{l}\text { Singap } \\
\text { ore }\end{array}$ & $\begin{array}{l}\text { Thaila } \\
\text { nd }\end{array}$ & $\begin{array}{l}\text { Vietn } \\
\text { am }\end{array}$ & $\begin{array}{l}\text { Banglad } \\
\text { esh }\end{array}$ & $\begin{array}{l}\text { Ind } \\
\text { ia }\end{array}$ & $\begin{array}{l}\text { Pakist } \\
\text { an }\end{array}$ & $\begin{array}{l}\text { Sri } \\
\text { Lan } \\
\text { ka }\end{array}$ \\
\hline China & & 25 & 23 & 25 & 21 & 21 & 21 & 20 & 21 & 21 & 21 & 21 & 21 & 21 & 23 & 23 & 23 & 23 \\
\hline Japan & 0 & & 0 & 0 & 0 & 0 & 0 & 0 & 0 & 0 & 0 & 0 & 0 & 0 & 0 & 0 & 0 & 0 \\
\hline $\begin{array}{l}\text { South } \\
\text { Korea }\end{array}$ & 8 & 8 & & 8 & 0 & 0 & 0 & 0 & 0 & 0 & 0 & 0 & 0 & 0 & 0 & 0 & 8 & 8 \\
\hline Taiwan & 17 & 17 & 17 & & 17 & 17 & 17 & 17 & 17 & 17 & 17 & 17 & 17 & 17 & 17 & 17 & 17 & 17 \\
\hline Brunei & 0 & 0 & 0 & 0 & & 0 & 0 & 0 & 0 & 0 & 0 & 0 & 0 & 0 & 0 & 0 & 0 & 0 \\
\hline $\begin{array}{l}\text { Cambo } \\
\text { dia }\end{array}$ & 0 & 27 & 28 & 28 & 0 & & 0 & 0 & 0 & 0 & 0 & 0 & 0 & 0 & 28 & 16 & 28 & 28 \\
\hline $\begin{array}{l}\text { Indones } \\
\text { ia }\end{array}$ & 27 & 29 & 18 & 29 & 0 & 0 & & 0 & 0 & 0 & 0 & 0 & 0 & 0 & 29 & 24 & 29 & 29 \\
\hline $\begin{array}{l}\text { Lao } \\
\text { PDR }\end{array}$ & 15 & 40 & 40 & 40 & 0 & 0 & 0 & & 0 & 0 & 0 & 0 & 0 & 0 & 40 & 40 & 40 & 40 \\
\hline $\begin{array}{l}\text { Malaysi } \\
\text { a }\end{array}$ & 22 & 3 & 21 & 23 & 0 & 0 & 0 & 0 & & 0 & 0 & 0 & 0 & 0 & 23 & 23 & 16 & 23 \\
\hline $\begin{array}{l}\text { Myanm } \\
\text { ar }\end{array}$ & 24 & 27 & 27 & 27 & 0 & 0 & 0 & 0 & 0 & & 0 & 0 & 0 & 0 & 27 & 27 & 27 & 27 \\
\hline $\begin{array}{l}\text { Philippi } \\
\text { nes }\end{array}$ & 29 & 30 & 30 & 30 & 0 & 0 & 0 & 0 & 0 & 0 & & 0 & 0 & 0 & 30 & 30 & 30 & 30 \\
\hline $\begin{array}{l}\text { Singapo } \\
\text { re }\end{array}$ & 0 & 0 & 0 & 0 & 0 & 0 & 0 & 0 & 0 & 0 & 0 & & 0 & 0 & 0 & 0 & 0 & 0 \\
\hline $\begin{array}{l}\text { Thailan } \\
d\end{array}$ & 40 & 62 & 66 & 75 & 0 & 0 & 0 & 0 & 0 & 0 & 0 & 0 & & 0 & 75 & 75 & 75 & 75 \\
\hline Vietnam & 54 & 49 & 50 & 55 & 0 & 0 & 0 & 0 & 0 & 0 & 0 & 0 & 0 & & 55 & 55 & 55 & 55 \\
\hline $\begin{array}{l}\text { Banglad } \\
\text { esh }\end{array}$ & 20 & 20 & 20 & 20 & 20 & 20 & 20 & 20 & 20 & 20 & 20 & 20 & 20 & 20 & & 20 & 20 & 20 \\
\hline India & 100 & 100 & 100 & 100 & 100 & 0 & 100 & 0 & 100 & 100 & 100 & 100 & 100 & 100 & 31 & & 10 & 0 \\
\hline $\begin{array}{l}\text { Pakista } \\
\mathrm{n}\end{array}$ & 87 & 87 & 87 & 87 & 87 & 87 & 87 & 87 & 87 & 87 & 87 & 87 & 87 & 87 & 87 & 87 & & 87 \\
\hline $\begin{array}{l}\text { Sri } \\
\text { Lanka }\end{array}$ & 21 & 21 & 19 & 21 & 21 & 21 & 21 & 21 & 21 & 21 & 19 & 19 & 19 & 19 & 19 & 19 & 19 & \\
\hline
\end{tabular}


Source: Trade Map, ICT database. Retrieved on 13 May 2017. How to read the table? China applies a tariff of $25 \%$ on cars imported from Japan, $23 \%$ on cars imported from Korea, $25 \%$ on cars imported from Taiwan (China)...

Note: The tariff data available in Trade Map is uniquely based on the minimum rates applied by the importing country(s). Ad valorem equivalent (AVE) tariffs are calculated using the World Tariff Profile

(WTP) methodology. At the HS4 level, tariffs aggregations are calculated using the country's Reference group imports as weights. 
Table 2. Equivalent ad valorem tariff applied by importer country to exporter country on automobile parts and components (HS 8708)

\begin{tabular}{|c|c|c|c|c|c|c|c|c|c|c|c|c|c|c|c|c|c|c|}
\hline Importer & Chi & $\begin{array}{l}\text { Jap } \\
\text { an }\end{array}$ & $\begin{array}{l}\text { Sou } \\
\text { th } \\
\text { Kor } \\
\text { ea }\end{array}$ & $\begin{array}{l}\text { Taiw } \\
\text { an }\end{array}$ & nei & $\begin{array}{l}\text { Cambo } \\
\text { dia }\end{array}$ & $\begin{array}{l}\text { Indone } \\
\text { sia }\end{array}$ & $\begin{array}{l}\text { La } \\
\text { o } \\
\text { PD } \\
\mathrm{R}\end{array}$ & $\begin{array}{l}\text { Malay } \\
\text { sia }\end{array}$ & $\begin{array}{l}\text { Myan } \\
\text { mar }\end{array}$ & $\begin{array}{l}\text { Philippi } \\
\text { nes }\end{array}$ & $\begin{array}{l}\text { Singap } \\
\text { ore }\end{array}$ & $\begin{array}{l}\text { Thaila } \\
\text { nd }\end{array}$ & $\begin{array}{l}\text { Vietn } \\
\text { am }\end{array}$ & $\begin{array}{l}\text { Banglad } \\
\text { esh }\end{array}$ & \begin{tabular}{|l} 
Ind \\
ia
\end{tabular} & $\begin{array}{l}\text { Pakist } \\
\text { an }\end{array}$ & $\begin{array}{l}\text { Sri } \\
\text { Lan } \\
\text { ka }\end{array}$ \\
\hline China & & 10 & 9 & 6 & 2 & 1 & 2 & 2 & 2 & 1 & 2 & 2 & 2 & 2 & 2 & 9 & 6 & 9 \\
\hline Japan & 0 & & 0 & 0 & 0 & 0 & 0 & 0 & 0 & 0 & 0 & 0 & 0 & 0 & 0 & 0 & 0 & 0 \\
\hline $\begin{array}{l}\text { South } \\
\text { Korea }\end{array}$ & 6 & 8 & & 8 & 0 & 0 & 0 & 0 & 0 & 0 & 0 & 0 & 0 & 0 & 0 & 0 & 8 & 6 \\
\hline Taiwan & 8 & 8 & 8 & & 8 & 8 & 8 & 8 & 8 & 8 & 8 & 8 & 8 & 8 & 6 & 8 & 8 & 8 \\
\hline Brunei & 0 & 0 & 16 & 20 & & 0 & 0 & 0 & 0 & 0 & 0 & 0 & 0 & 0 & 20 & 0 & 20 & 20 \\
\hline $\begin{array}{l}\text { Cambo } \\
\text { dia }\end{array}$ & 0 & 14 & 9 & 14 & 0 & & 0 & 0 & 0 & 0 & 0 & 0 & 0 & 0 & 14 & 10 & 14 & 14 \\
\hline $\begin{array}{l}\text { Indones } \\
\text { ia }\end{array}$ & 8 & 10 & 6 & 10 & 0 & & & 0 & 0 & 0 & 0 & 0 & 0 & 0 & 10 & 10 & 10 & 10 \\
\hline $\begin{array}{l}\text { Lao } \\
\text { PDR }\end{array}$ & 0 & 10 & 10 & 10 & 0 & 0 & 0 & & 0 & 0 & 0 & 0 & 0 & 0 & 10 & 8 & 10 & 10 \\
\hline $\begin{array}{l}\text { Malaysi } \\
\text { a }\end{array}$ & 0 & 0 & 11 & 15 & 0 & 0 & 0 & 0 & & 0 & 0 & 0 & 0 & 0 & 15 & 7 & 11 & 15 \\
\hline $\begin{array}{l}\text { Myanm } \\
\text { ar }\end{array}$ & 0 & 4 & 4 & 4 & 0 & 0 & 0 & 0 & 0 & & 0 & 0 & 0 & 0 & 4 & 4 & 4 & 4 \\
\hline $\begin{array}{l}\text { Philippi } \\
\text { nes }\end{array}$ & 11 & 11 & 11 & 11 & 0 & 0 & 0 & 0 & 0 & 0 & & 0 & 0 & 0 & 11 & 11 & 11 & 11 \\
\hline $\begin{array}{l}\text { Singapo } \\
\text { re }\end{array}$ & 0 & 0 & 0 & 0 & 0 & 0 & 0 & 0 & 0 & 0 & 0 & & 0 & 0 & 0 & 0 & 0 & 0 \\
\hline $\begin{array}{l}\text { Thailan } \\
\text { d }\end{array}$ & 11 & 19 & 11 & 24 & 0 & 0 & 0 & 0 & 0 & 0 & 0 & 0 & & 0 & 24 & 22 & 24 & 24 \\
\hline Vietnam & 5 & 5 & 11 & 14 & 0 & 0 & 0 & 0 & 0 & 0 & 0 & 0 & 0 & & 14 & 14 & 14 & 14 \\
\hline $\begin{array}{l}\text { Banglad } \\
\text { esh }\end{array}$ & 10 & 10 & 10 & 10 & 10 & 10 & 10 & 10 & 10 & 10 & 10 & 10 & 10 & 10 & & 10 & 10 & 10 \\
\hline India & 10 & 10 & 10 & 10 & 10 & 0 & 10 & 0 & 10 & 10 & 10 & 10 & 8 & 10 & 0 & & 10 & 0 \\
\hline $\begin{array}{l}\text { Pakista } \\
\mathrm{n}\end{array}$ & 35 & 35 & 35 & 35 & 35 & 35 & 35 & 35 & 35 & 35 & 35 & 35 & 35 & 35 & 35 & 35 & & 33 \\
\hline $\begin{array}{l}\text { Sri } \\
\text { Lanka }\end{array}$ & 102 & 102 & 102 & 102 & 102 & 102 & 102 & $\begin{array}{l}10 \\
2\end{array}$ & 102 & 102 & 102 & 102 & 102 & 102 & 58 & 85 & 86 & \\
\hline
\end{tabular}


How to read the table? China applies a tariff of $10 \%$ on parts and components imported from Japan, $9 \%$ on parts and components imported from Korea... Note: The tariff data available in Trade Map is uniquely based on the minimum rates applied by the importing country(s). Ad valorem equivalent (AVE) tariffs are calculated using the World Tariff Profile

(WTP) methodology. At the HS4 level, tariffs aggregations are calculated using the country's Reference group imports as weights. 
Table 3. Average distance of suppliers from importing countries, for vehicles for the transport of less than 10 persons (HS 8703) and vehicle components and parts (HS 8708), and all products, in $\mathrm{km}$

\begin{tabular}{|l|c|c|c|}
\hline \multicolumn{1}{|c|}{ Imports } & 8703 & 8708 & All products \\
\hline Asia & 7590 & 5121 & 5455 \\
\hline Northeast Asia & 8027 & 5192 & 4999 \\
\hline ASEAN & 5221 & 4790 & 4505 \\
\hline South Asia & 5111 & 5612 & 5529 \\
\hline NAFTA & 5809 & 5266 & 7175 \\
\hline EU 28 & 1981 & 1797 & 3001 \\
\hline World & 4901 & 4001 & 5125 \\
\hline
\end{tabular}

Source: ICT and COMTRADE. Author's calculations using countries' weight in the relevant region.

Table 4. Average distance of importing markets from exporting countries for vehicles for the transport of less than 10 persons (HS 8703) and vehicle components and parts (HS 8708), and all products, in $\mathrm{km}$

\begin{tabular}{|l|c|c|c|}
\hline \multicolumn{1}{|c|}{ Exports } & 8703 & 8708 & All products \\
\hline Asia & 8825 & 7353 & 5775 \\
\hline Northeast Asia & 9048 & 7572 & 5763 \\
\hline ASEAN & 6658 & 5662 & 5557 \\
\hline South Asia & 8239 & 8447 & 6574 \\
\hline NAFTA & 4219 & 2741 & 5376 \\
\hline EU 28 & 5130 & 2508 & 2735 \\
\hline World & 4709 & 4009 & 4695 \\
\hline
\end{tabular}

Source: ICT and COMTRADE. Author's calculations using countries' weight in the relevant region. 
Figure 1: Import distance of automobile components by selected Asian subregion

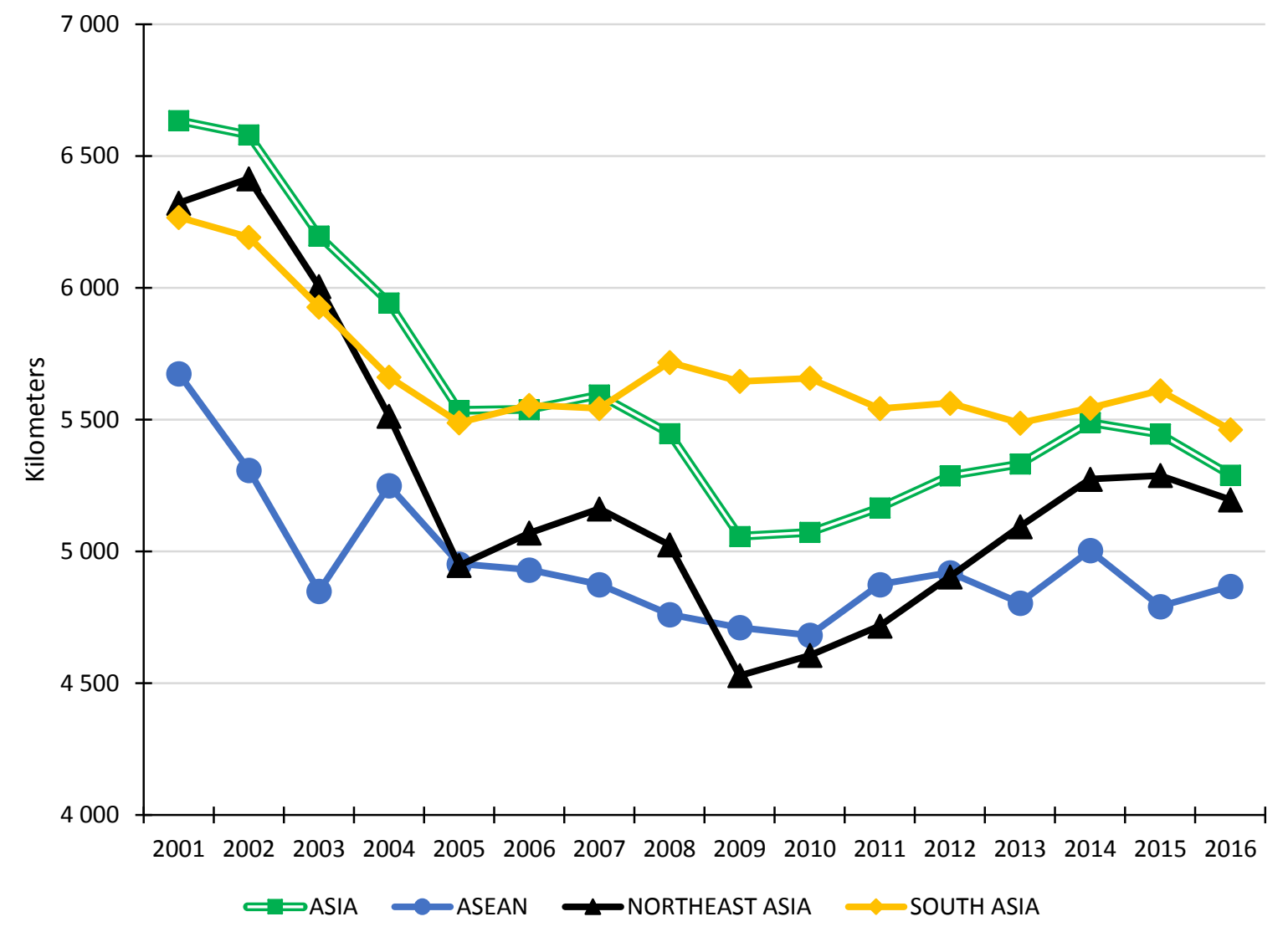

Source: Author's calculations with ICT database based on COMTRADE data 
Figure 2: Breakdown of Asian auto components imports by subregions
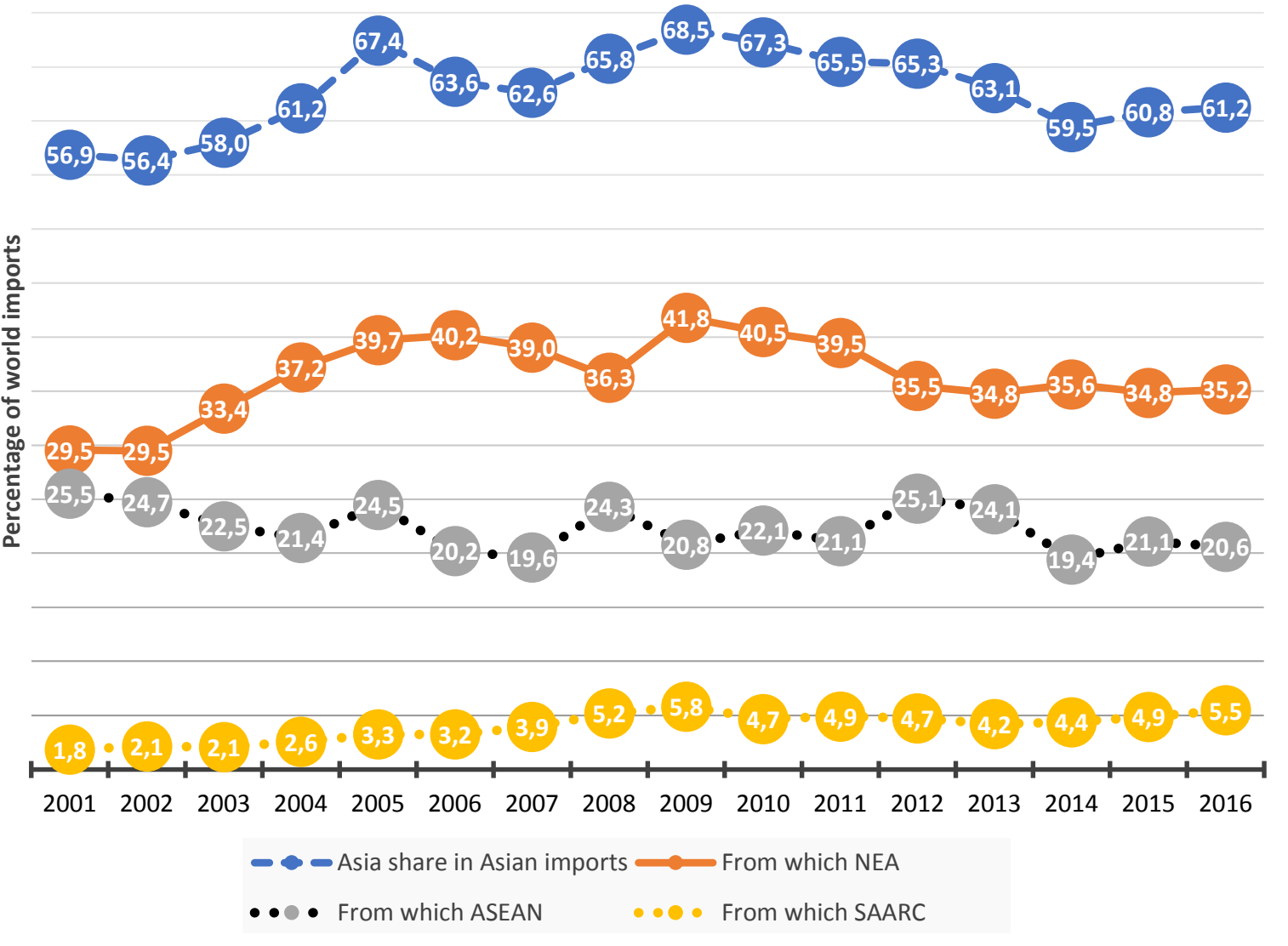

Source: Author's calculations with ICT database based on COMTRADE. 
Figure 3: Share of Japan in imports of automobile parts and components of selected countries

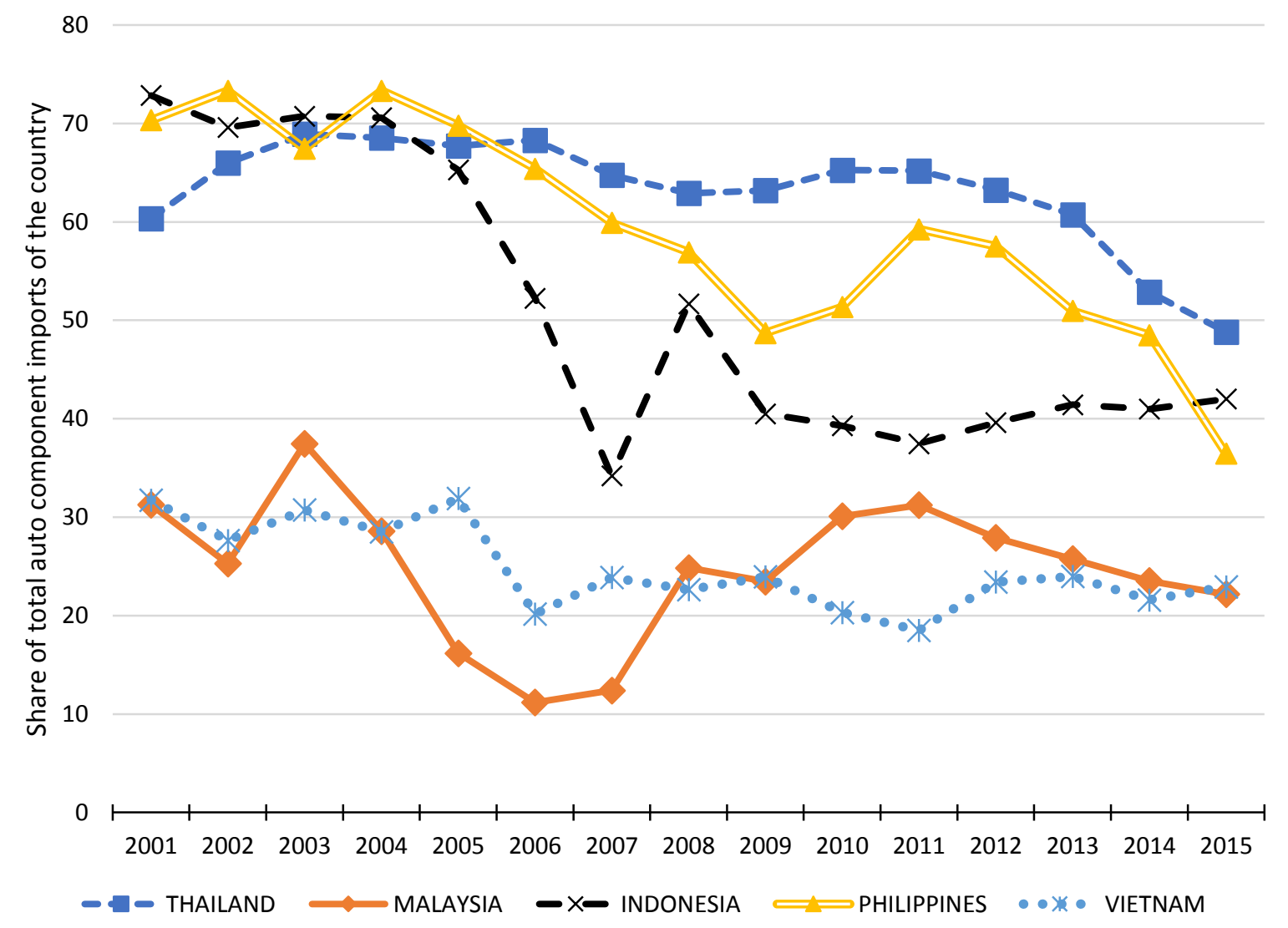

Source: Author's calculations with ICT database based on COMTRADE 
Figure 4: Share of China in imports of automobile parts and components of selected countries

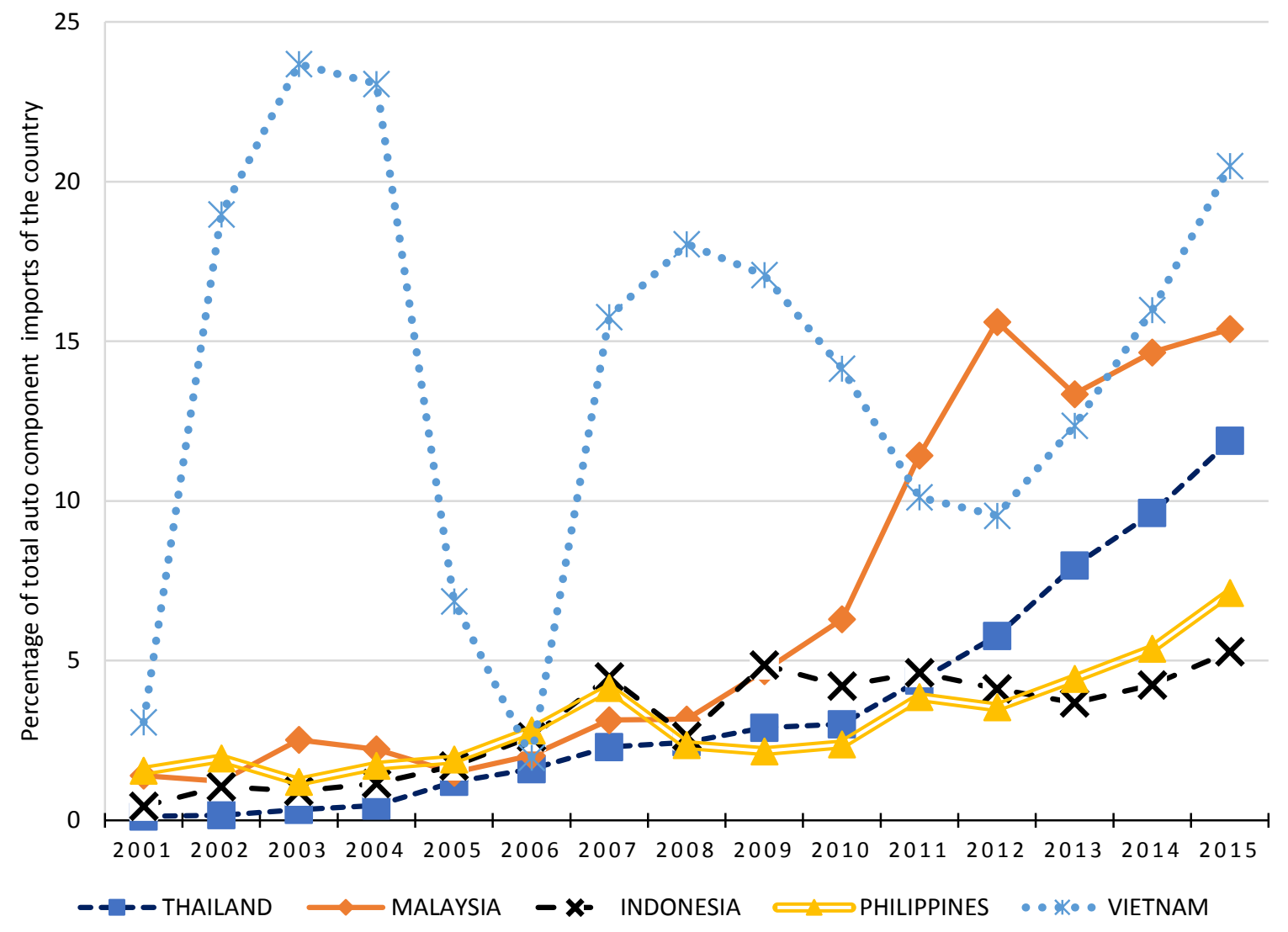

Source: Author's calculations with ICT database based on COMTRADE 
Figure 5: India's imports of automobile components by country and region of origin

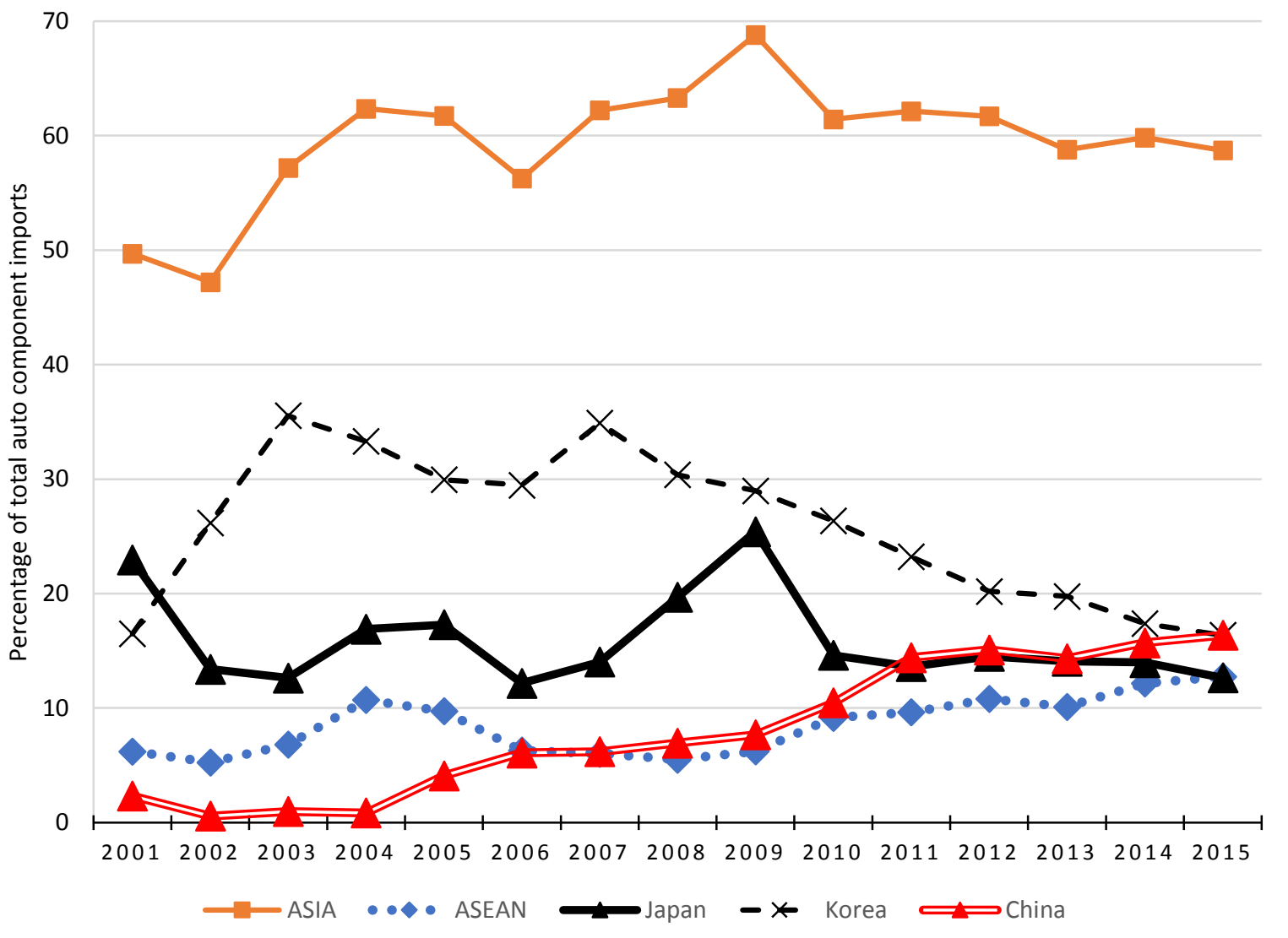

Source: Author's calculations with ICT database based on COMTRADE 
Figure 6: Japan's imports of automobile components by country and region of origin

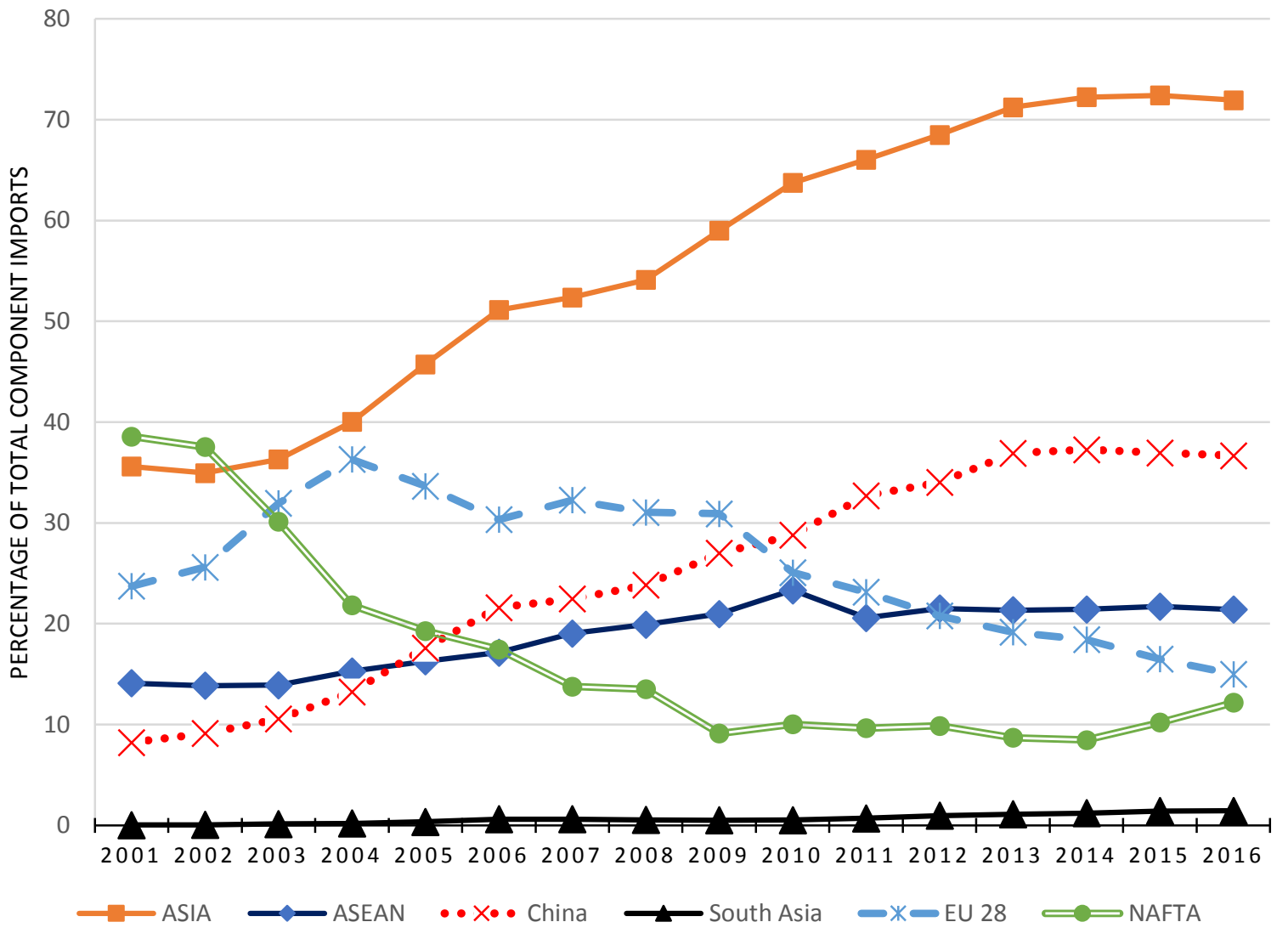


Figure 7: China's imports of automobile components by country and region of origin

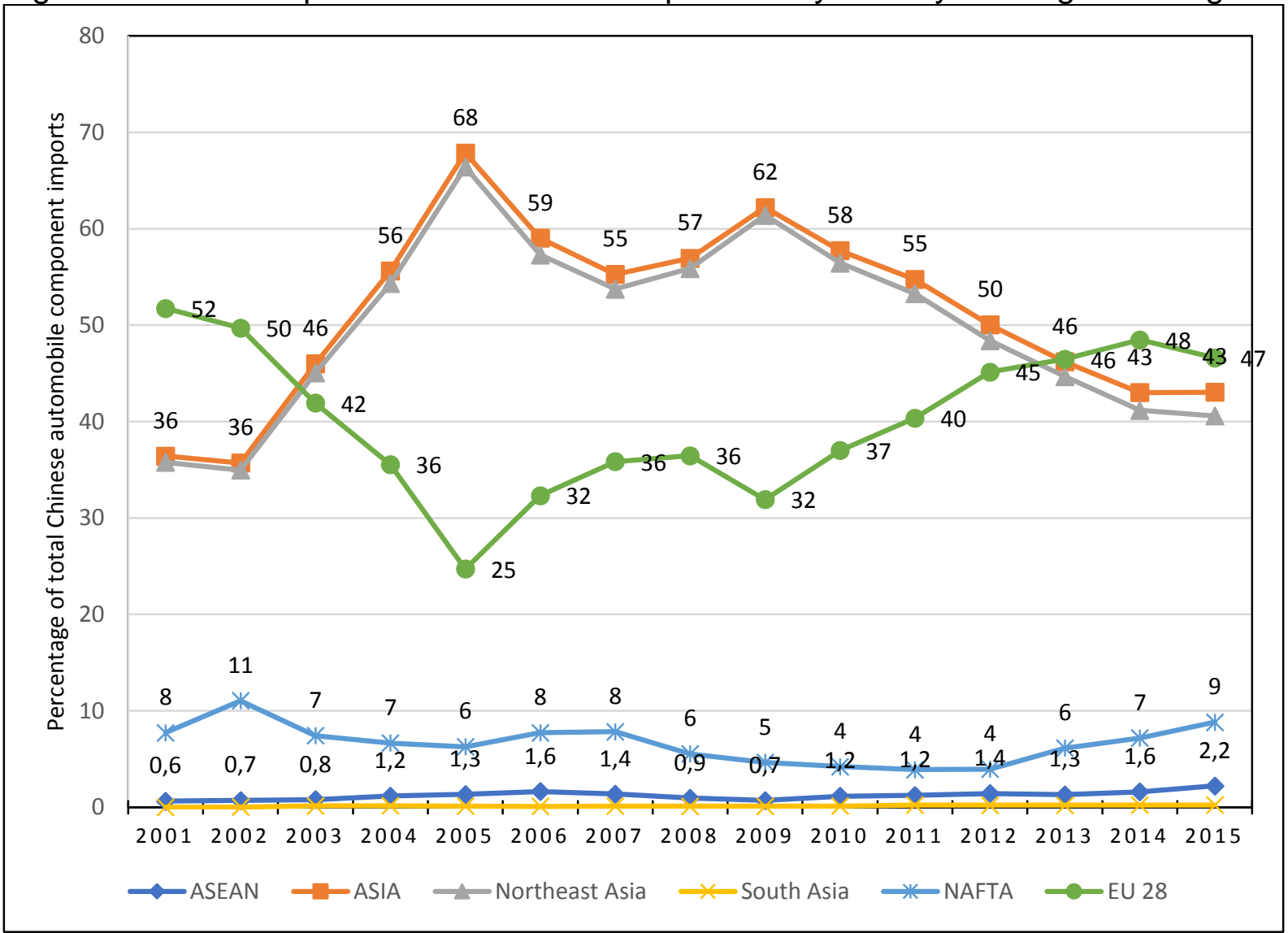




\section{References}

Abe, M. (2013) 'Expansion of global value chains in Asian developing countries: automotive case study in the Mekong sub-region', in Global value chains in a changing world, eds. D. K. Elms and P. Low (Geneva: World Trade Organization Geneva)

ADB (2010) 'Key Indicators for Asia and the Pacific 2010. Special Chapter: The Rise of Asia's Middle Class', in Key Indicators for Asia and the Pacific, (Manila: Asian Development Ban k)

Agustin, T. L. D. \& M. Schröder (2014) 'The Indian Automotive Industry and the ASEAN Supply Chain Relations', in Automobile and Auto Components Industries in ASEAN, (Jakarta: ERIA \& Waseda University)

Ahmed, V. \& S. Batool (2017) 'India-Pakistan Trade: Perspectives from the Automobile Sector in Pakistan', in India-Pakistan Trade Normalisation: The Unfinished Economic Agenda, eds. N. Taneja and I. Dayal (Singapore: Springer Singapore)

Amighini, A. \& S. Gorgoni (2014) 'The international reorganisation of auto production', The World Economy, 37, 923-52

Baldwin, R. (2013) 'Global Supply Chains: Why They Emerged, Why They Matter, and Where They Are Going', in Global value chains in a changing world, eds. D. K. Elms and P. Low (Geneva, Switzerland: WTO Publications)

Baldwin, R. \& J. Lopez-Gonzalez (2015) 'Supply-chain Trade: A Portrait of Global Patterns and Several Testable Hypotheses', The World Economy, 38, 1682-721

Bungsche, H. (2010) 'Ambitious Plans And Hard Realities: The Chinese Automobile Supply Parts Industry In A Challenging Competitive Environment', in The Prospects and Limits to the Development of the Automotive Periphery,, ed. GERPISA (Paris: CCFA)

Cheewatrakoolpong, K., C. Sabhasri \& N. Bunditwattanawong (2013) 'Impact of the ASEAN Economic Community on ASEAN Production Networks', ADBI Working Paper Series,

De Backer, K. \& S. Miroudot (2014) 'Mapping Global Value Chains', European Central Bank Working Paper Series, 1677

De Benedictis, L. \& L. Tajoli (2011) 'The World Trade Network', The World Economy, 34, 141754

Duval, Y. \& E. Feyler (2016) 'Intra-and Extraregional Trade Costs of ASEAN Economies: Implications for Asian Regional Integration', in ASEAN Economic Community, eds. B. Jetin and M. Mikic (New York: Springer)

Escaith, H. \& S. Inomata (2013) 'Geometry of global value chains in East Asia: the role of industrial networks and trade policies', in Global value chains in a changing world, eds. D. K. Elms and P. Low (Geneva: World Trade Organization)

Freyssenet, M., K. Shimizu \& G. Volpato (2003) Globalization Or Regionalization of the American and Asian Car Industry?, (Basingtok, New York: Palgrave Mcmillan) 
Guiheux, G. \& Y. Lecler (2000) 'Japanese Car Manufacturers and Component Makers in the ASEAN Region: a Case of Expatriation under Duress - or a Strategy of Regionally Integrated Production', in Global Strategies and Local Realities: The Auto Industry in Emerging Markets, eds. J. Humphrey, Y. Lecler and M. S. Salerno (London: Palgrave Macmillan UK)

Helble, M. \& B.-L. Ngiang (2016) 'From global factory to global mall? East Asia's changing trade composition and orientation', Japan and the World Economy, 39, 37-47

Henderson, J., P. Dicken, M. Hess, N. Coe \& H. W.-C. Yeung (2002) 'Global Production Networks and the Analysis of Economic Development', Review of International Political Economy, 9, 43664

Jetin, B. (2012) 'The role of China in the global capitalist economy', in China's Rise - Strength and Fragility, ed. A. Loong-Yu (Pontypool: Merlin Press)

Jetin, B. (2015) 'Introduction', in Global Automobile Demand: Major Trends in Mature Economies, ed. B. Jetin (Basingtoke: Palgrave McMillan)

Jetin, B. \& M. Mikic (2016) ASEAN Economic Community: A Model for Asia-wide Regional Integration?, (New York: Springer)

Kobayashi, H. \& Y. Jin (2015) 'The CLMV Automobile and Auto Parts Industry', (Jakarta: ERIA)

Kobayashi, H., Y. Jin \& M. Schroeder (2015) 'ASEAN economic community and the regional automotive industry: impact of ASEAN economic integration on two types of automotive production in Southeast Asia', International Journal of Automotive Technology and Management, 15, 268-91

Los, B., M. P. Timmer \& G. J. Vries (2015) 'How global are global value chains? A new approach to measure international fragmentation', Journal of Regional Science, 55, 66-92

Lung, Y. \& R. Van Tulder (2004) 'Introduction: in search of a viable automobile space', in Cars, Carriers of regionalism?, eds. C. Jorge, Y. Lung and R. Van Tulder (Houndmills, Basingstoke and New York: Palgrave McMillan)

Mikic, M. (2016) 'Trade Implications of the ASEAN+ Agreements for Other Asian Countries', in ASEAN Economic Community: A Model for Asia-wide Regional Integration?, eds. B. Jetin and M. Mikic: Palgrave)

Nag, B. (2017) 'Assessing the Future of Trade in the Automobile Sector Between India and Pakistan: Implications of Abolishing the Negative List', in India-Pakistan Trade Normalisation: Springer)

Okabe, M. \& S. Urata (2014) 'The impact of AFTA on intra-AFTA trade', Journal of Asian Economics, 35, 12-31

Pasha, M. (2011) 'Linkages between regional trade agreements and international production networks: Evidence from five case studies in Asia', in Fighting Irrelevance: The Role of Regional Trade Agreements in International Production Networks in Asia, ed. UNESCAP (Bangkok: UNESCAP) 
Peel, M. (2017) 'Vietnam's drivers trade up from two wheels to four', in Financial Times, (London:

Schott, J. J., E. Jung \& C. Cimino-Isaacs (2015) 'An Assessment of the Korea-China Free Trade Agreement', Peterson Institute for international economics.-2015. № PB15-24.-P, 1-15

Sturgeon, T. J. \& O. Memedovic (2010) 'Mapping Global Value Chains: Intermediate Goods Trade and Structural Change in the World Economy,' United Nations Industrial Development Organization, UNIDO Working"Paper 05/2010

Sturgeon, T. J. \& J. Van Biesebroeck (2011) 'Global value chains in the automotive industry: an enhanced role for developing countries?', International Journal of Technological Learning, Innovation and Development, 4, 181-205

Timmer, M. P., E. Dietzenbacher, B. Los, R. Stehrer \& G. J. de Vries (2015) 'An Illustrated User Guide to the World Input-Output Database: the Case of Global Automotive Production', Review of International Economics, 23, 575-605

Yoshimatsu, H. (2002) 'Preferences, interests, and regional integration: the development of the ASEAN industrial cooperation arrangement', Review of International Political Economy, 9, $123-49$

Notes 
1 In 2015, Asia sold around 44 million vehicles versus 21 million in North America and 16.5 million in Europe. Asia produced about 47 million vehicles, North America 18 million and Europe 21 million. Asia includes Australia and Iran. Europe is defined in the broad sense and includes the EU 27 countries, other European countries, Russia and Turkey. Vehicle is defined as all personal and commercial vehicles. Source OICA.

${ }^{2}$ In 2015, at the two-digit level, the category 87 in Harmonised system of the United nations, "vehicles other than railway or tramway rolling stock, and parts and accessories thereof" comes at the fourth rank with a share of $8.1 \%$ of world exports. At the four digit level, "Motor cars and other motor vehicles principally designed for the transport of persons" come second, just after "Petroleum oils and oils obtained from bituminous minerals, crude" in world exports. Source: Trade World Map, ICT.

${ }^{3}$ Many terms are used in the literature to refer more or less to the same reality, the fact that products are not made in a single country: fragmented production, global production network, global value chains, global commodity chain, trade in value-added, production sharing, supply chains, outsourcing, offshoring, vertical integration. We prefer the term "global production network" for reasons that are explained at length in Henderson, J., P. Dicken, M. Hess, N. Coe \& H. W.-C. Yeung (2002) 'Global Production Networks and the Analysis of Economic Development', Review of International Political Economy, 9, 436-64.

${ }^{4}$ Author's calculations with data from CCFA, 2016, ( $p$ 9-10) estimated by dividing imports by sales of total vehicles expressed in units.

${ }^{5}$ Founded in 1967, ASEAN member states include Brunei Darussalam, Cambodia, Indonesia, Lao PDR, Malaysia, Myanmar, the Philippines, Singapore, Thailand and Vietnam.

${ }^{6}$ Its member states include Afghanistan, Bangladesh, Bhutan, India, Nepal, the Maldives, Pakistan and Sri Lanka.

${ }^{7}$ In fact, one could argue that the regional process of integration involves Asia and the Pacific, Asia and Central Asia (including the Federation of Russia) and Asia and the Middle East. These regions are important as buyers of final products manufactured in Asia but are not integrated in the fragmented production networks and will therefore not be included in the scope of investigation.

${ }^{8}$ Intermediates include primary goods, parts and components, and semi-finished products. Some authors like Athukorala (2015) chose to focus on the trade of parts and components which better track the specialization of a country in one segment or task in the fragmented process of production.

${ }^{9}$ China, Chinese Taipei, Korea, Japan, India, Cambodia, Indonesia, Malaysia, the Philippines, Singapore, Thailand, Vietnam.

${ }^{10}$ The Index of fragmentation equals one for a final industry without production stages. It is above 2.5 for the automobile industry for most countries and above 3 in the case of China, Korea and Japan. Source: De Backer and Minoudot, op. cit. Figure 12 page 22.

${ }^{11}$ More precisely, they measure the evolution of the geographical distances between the most important cities in terms of population of bilateral pairs of countries: Japan, Korea, China and ASEAN member states (AMS) with their trading partners over the period 1999-2014.

12 NAFTA, (Canada, Mexico and the USA), the 27 countries of the EU of 2011, and East Asia defined as China, Japan, South Korea and Taiwan.

${ }^{13}$ The authors use the International Standard Industrial Classification of All Economic Activities, (ISIC rev. 3) in which transport equipment is divided in industries 34 (Manufacture of motor vehicles, trailers and semitrailers) and 35 (Manufacture of other transport equipment), the latter including ships, railways, aircraft and spacecraft. Although industry 34 is usually the largest among the two, it is not exactly the automobile industry. ${ }^{14}$ The authors focus mostly on the period 1995-2008 because the international crisis of 2009 provoked a dip in the share of foreign value added. It recovered its pre-crisis level in 2010 and 2011.

${ }^{15}$ In their article, Timmer et al. state that they analyse the automobile products which means the category 34 (motor vehicles...). But the source given for their tables and charts relates to the whole transport equipment, which adds the category 35 which includes completely different products like planes, locomotives and ships.

${ }^{16}$ Western Europe, Eastern Europe North America, Latin America, Asia and Oceania. Northeast, Southeast and South Asian countries are included in the networks as long as their exports amounts to at least $1 \%$ of world trade of a specific component group.

${ }^{17}$ In electrical and electric parts and in Engines and parts.

18 In respectively, electrical and electric parts, in miscellaneous parts and in Engines and parts. The exception is in rubber and metallic parts.

${ }^{19}$ This group includes important items such as chassis fitted with engines, bodies, bumpers, brakes, gearboxes, drive-axles and seats.

${ }^{20}$ Namely Brunei, Indonesia, Malaysia, the Philippines, Singapore and Thailand. 
${ }^{21}$ According to Peel, M. (2017) 'Vietnam's drivers trade up from two wheels to four', in Financial Times, (London: , in 2017, the cut in import taxes has generated a boom in the market for new cars in Vietnam.

22 In the case of Vietnam, "shipments from Indonesia jumped from almost zero in the first two months of 2016 to more than 3,000 this year, while those from Thailand climbed almost fourfold to more than 5,700, according to Vietnam's customs authority" Ibid.

${ }^{23}$ The agreement with China was signed in 2005 for goods, in 2007 for services and in 2009 for investment. The agreement with Korea was signed in 2006, with Japan in 2008 and India in 2009.

${ }^{24}$ See below for detail explanation of the classification.

${ }^{25}$ Comprehensive trade costs represents all extra costs involved in trading goods internationally rather than domestically, i.e. tariffs and non-tariffs measures (NTM). As tariffs have been removed within ASEAN, the authors focus on NTM. The data comes from the ESCAP-World Bank database. For a detailed description, see Duval and Feyler, op cit. page 155-56.

${ }^{26}$ Source: Trade Competitiveness Map, International Trade Centre (ITC). The primary source of the data for the geographical distance between two countries is the CEPII database (Mayer T. \& S. Zignago (2006), "GeoDist: the CEPII's distances and geographical database", MPRA Paper 31243). It measures the average distance between two countries corresponding to geographical weights between main economic centres of each country. Downloaded on 10 February 2017 at:

http://www.trademap.org/countrymap/Country SelProduct Graph.aspx?nvpm=1|||||TOTAL|||2|1|1|2|1|| $\underline{1|2| 1 \mid}$

27 The Harmonized System (HS) is an international nomenclature defined by the World Customs Organisation (WCO) for the classification of products. For more details, see http://www.trademap.org/stGlossary.aspx

${ }^{28}$ In 2015, automobile products (HS87) accounted for $8 \%$ of global exports, which placed them at the fourth rank at world level, the first rank being occupied by "electrical machinery" (HS85) which amounted to $14 \%$ of global trade. Automobile products are therefore at the core of global trade.

${ }^{29}$ The category 8708 is broad as it includes not only parts and components for cars but also for vehicles for the transport of more than 10 persons, for the transport of goods, special vehicles and tractors. The category 8703 covers vehicles for the transport of less than 10 persons such as sedans, SUVs, pick-ups, and station-wagons.

${ }^{30}$ Singapore combines a very high level of income per capita and one of the most competitive deep sea port of the world which makes it a hub for import and re-export of automobiles products on long distances.

${ }^{31}$ For instance, the distances between Jakarta and Tokyo, Jakarta and Beijing, Jakarta and Mumbai or JakartaNew Delhi, are respectively 5,753 km, 5,200 km and 4,684 km, $4990 \mathrm{~km}$

32 The longest distances are from Karachi to Tokyo or Colombo to Tokyo which are respectively around 6,900 $\mathrm{km}$ and $6,800 \mathrm{~km}$.

${ }^{33}$ Author's calculations with ICT database based on COMTRADE. 